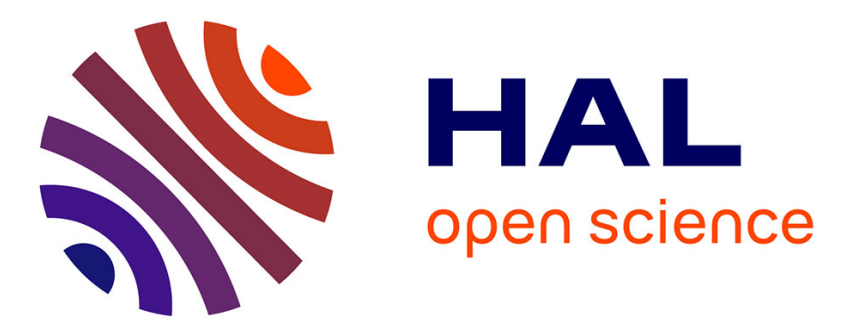

\title{
Physicochemical and Spectroscopic Characterization of Biofield Energy Treated p-Anisidine
}

Mahendra Kumar Trivedi, Alice Branton, Dahryn Trivedi, Gopal Nayak, Khemraj Bairwa, Snehasis Jana

\section{- To cite this version:}

Mahendra Kumar Trivedi, Alice Branton, Dahryn Trivedi, Gopal Nayak, Khemraj Bairwa, et al.. Physicochemical and Spectroscopic Characterization of Biofield Energy Treated p-Anisidine. Pharmaceutical Analytical Chemistry: Open Access, 2015, 1 (1). hal-01429166

\section{HAL Id: hal-01429166 \\ https://hal.science/hal-01429166}

Submitted on 7 Jan 2017

HAL is a multi-disciplinary open access archive for the deposit and dissemination of scientific research documents, whether they are published or not. The documents may come from teaching and research institutions in France or abroad, or from public or private research centers.
L'archive ouverte pluridisciplinaire HAL, est destinée au dépôt et à la diffusion de documents scientifiques de niveau recherche, publiés ou non, émanant des établissements d'enseignement et de recherche français ou étrangers, des laboratoires publics ou privés.

\section{(c)(1)}

Distributed under a Creative Commons Attribution| 4.0 International License 


\title{
Physicochemical and Spectroscopic Characterization of Biofield Energy Treated $p$-Anisidine
}

\author{
Mahendra Kumar Trivedi ${ }^{1}$, Alice Branton ${ }^{1}$, Dahryn Trivedi ${ }^{1}$, Gopal Nayak ${ }^{1}$, Khemraj Bairwa ${ }^{2}$ and Snehasis Jana ${ }^{\star \star}$ \\ ${ }^{1}$ Trivedi Global Inc., 10624 S Eastern Avenue Suite A-969, Henderson, NV 89052, USA \\ ${ }^{2}$ Trivedi Science Research Laboratory Pvt. Ltd., Hall-A, Chinar Mega Mall, Chinar Fortune City, Hoshangabad Rd., Bhopal, Madhya Pradesh, India
}

\begin{abstract}
The $p$-anisidine is widely used as chemical intermediate in the production of various dyes, pigments, and pharmaceuticals. This study was aimed to evaluate the effect of biofield energy treatment on the physicochemical and spectroscopic properties of $p$-anisidine. The study was performed after dividing the sample in two groups; one was remained as untreated and another was subjected to Mr. Trivedi's biofield energy treatment. Afterward, both the control and treated samples of $p$-anisidine were evaluated using X-ray diffraction (XRD), surface area analyzer differential scanning calorimetry (DSC), thermogravimetric analysis-derivative thermogravimetry (TGA-DTG), Fourier transform infrared (FT-IR), and ultraviolet-visible (UV-Vis) spectroscopy. The XRD analysis showed the increase in unit cell volume from $683.81 \rightarrow 690.18 \times 10^{-24} \mathrm{~cm}^{3}$ and crystallite size from $83.84 \rightarrow 84.62 \mathrm{~nm}$ in the treated sample with respect to the control. The surface area analysis exhibited the significant increase $(25.44 \%)$ in the surface area of treated sample as compared to control. The DSC thermogram of control $p$-anisidine showed the latent heat of fusion and melting temperature and $146.78 \mathrm{~J} / \mathrm{g}$ and $59.41^{\circ} \mathrm{C}$, respectively, which were slightly increased to 148.89 $\mathrm{J} / \mathrm{g}$ and $59.49^{\circ} \mathrm{C}$, respectively after biofield treatment. The TGA analysis showed the onset temperature of thermal degradation at $134.68^{\circ} \mathrm{C}$ in the control sample that was increased to $150.02^{\circ} \mathrm{C}$ after biofield treatment. The result showed about $11.39 \%$ increase in onset temperature of thermal degradation of treated $p$-anisidine as compared to the control. Moreover, the $T_{\max }$ (temperature at which maximum thermal degradation occurs) was also increased slightly from $165.99^{\circ} \mathrm{C}$ (control) to $168.10^{\circ} \mathrm{C}$ (treated). This indicated the high thermal stability of treated $p$-anisidine as compared to the control. However, the FT-IR and UV spectroscopic studies did not show any significant changes in the spectral properties of treated $p$-anisidine with respect to the control.
\end{abstract}

All together, the XRD, surface area and thermal analysis suggest that Mr. Trivedi's biofield energy treatment has the impact on physical and thermal properties of the treated $p$-anisidine.

Keywords: $p$-Anisidine; X-ray diffraction; Surface area analysis; Differential scanning calorimetry; Fourier transform infrared; Biofield energy

\section{Abbreviations}

NIH: National Institute of Health; NCCAM: National Center for Complementary and Alternative Medicine; XRD: X-ray diffraction; DSC: Differential scanning calorimetry; TGA: Thermogravimetric analysis; DTG: Derivative Thermogravimetry; FT-IR: Fourier transforms infrared

\section{Introduction}

Anisidine is an aromatic amine (methoxyaniline) and exists in three isomeric forms i.e., ortho, meta, and $p$-anisidine [1]. The $p$-anisidine is widely used as an intermediate in the production of numerous azo and triphenylmethane dyes, and pigments. It is also used in the production of pharmaceuticals including the guaiacol expectorant [2], as an antioxidant for polymercaptan resins, and as a corrosion inhibitor for steel [3]. Apart from the beneficial use of $p$-anisidine, it is toxic for human beings. The acute exposure may cause skin irritation, whereas the chronic exposure may cause headaches, vertigo, and blood complications like sulfhemoglobin, and methemoglobin $[3,4]$. The oral exposure to anisidine hydrochloride resulted in cancer of the urinary bladder in male and female rats [5]. By considering the importance of $p$-anisidine as an intermediate for the production of various dyes, pharmaceuticals and several other organic products, it is advantageous to find out an alternate approach that can enhance the physicochemical and thermal properties of $p$-anisidine in the useful way.

Recently, healing therapy or therapeutic touch is used as an alternative treatment approach in several fields, and known as the biofield energy treatment. The National Institute of Health/National Center for Complementary and Alternative Medicine (NIH/NCCAM) considered the biofield energy (putative energy fields) treatment in the subcategory of energy therapies used to promote health and healing $[6,7]$. The biofield treatment is being applied in the healing process to reduce the anxiety, pain, and to promote the overall health of human being $[8,9]$. Previously, it was reported that all the electrical processes occurring in the human body have strong correlation with the magnetic field [10]. It is well known that moving charged particles like ions, atoms, electrons etc. produces the electromagnetic radiation [11]. Similarly, the moving ions, and charged particles in the human body also produced the bioenergetic field that permeates and surrounding the human body. This bioenergetic field is called as biofield and energy associated with this field is known as the biofield energy [12]. The effect of biofield has been reported by several researchers on bacterial cultures [13], antibiotics, proteins [14], and conformational change in

*Corresponding author: Snehasis Jana, Trivedi Science Research Laboratory Pvt. Ltd., Hall-A, Chinar Mega Mall, Chinar Fortune City, Hoshangabad Rd., Bhopal-462 026, Madhya Pradesh, India, Tel: +91-755-6660006; E-mail: publication@trivedisrl. com

Received September 09, 2015; Accepted September 19, 2015; Published September 27, 2015

Citation: Trivedi MK, Branton A, Trivedi D, Nayak G, Bairwa K, et al (2015) Physicochemical and Spectroscopic Characterization of Biofield Energy Treated p-Anisidine. Pharm Anal Chem Open Access 1: 102. doi:10.4172/24712698.1000102

Copyright: (c) 2015 Trivedi MK, et al. This is an open-access article distributed under the terms of the Creative Commons Attribution License, which permits unrestricted use, distribution, and reproduction in any medium, provided the original author and source are credited. 
DNA [15]. Thus, the human has the ability to harness the energy from the environment or Universe and transmit it to any living or nonliving object on the Globe. The object(s) receive the energy and respond into the useful way; this process is termed as biofield treatment. Mr. Trivedi's unique biofield energy treatment is also known as The Trivedi Effect'.

Recently, Mr. Trivedi's biofield energy treatment has been reported to alter the physicochemical and thermal properties of several metals and ceramics [16-18]. It has also been reported to alter the spectroscopic properties of various pharmaceutical drugs like chloramphenicol, tetracycline, metronidazole, and tinidazole $[19,20]$. Moreover, the biofield treatment has been studied in several fields like biotechnology research [21], agriculture research [22,23], and microbiology research $[24,25]$.

Based on the significant impact of biofield energy treatment and chemical importance of $p$-anisidine, this study was aimed to evaluate the effect of Mr. Trivedi's biofield energy treatment on physicochemical and spectroscopic properties of $p$-anisidine using several analytical techniques like XRD, surface area analysis, DSC, TGA-DTG analysis, FT-IR and UV-vis spectroscopy.

\section{Materials and Methods}

\section{Study design}

The $p$-anisidine was purchased from Loba Chemie Pvt. Ltd., India. The $p$-anisidine was divided into two groups; one was remained untreated (control group) and another was coded as treated group. The treated group in sealed pack was handed over to Mr. Trivedi for biofield energy treatment under laboratory conditions. Mr. Trivedi provided the biofield energy treatment to the treated group through his unique energy transmission process without touching the sample. Afterward, both the control and treated samples of $p$-anisidine were analyzed using various analytical techniques like X-ray diffraction (XRD), surface area analysis, differential scanning calorimetry (DSC), thermogravimetric analysis (TGA), Fourier transform infrared (FTIR), and ultraviolet-visible (UV-Vis) spectroscopy.

\section{XRD study}

The XRD analysis of the control and treated $p$-anisidine was carried out on Phillips, Holland PW 1710 X-ray diffractometer with nickel filter and copper anode. The wavelength used in XRD system was $1.54056 \AA$.

Percent change in unit cell volume was calculated using following equation

Percent change in unit cell volume $=\left[\left(\mathrm{V}_{\mathrm{t}}-\mathrm{V}_{\mathrm{c}}\right) / \mathrm{V}_{\mathrm{c}}\right] \times 100$

Here $V_{c}$ and $V_{t}$ are the unit cell volume of control and treated sample, respectively.

The molecular weight of atom was calculated using following equation:

Molecular weight $=$ number of protons $\times$ weight of a proton + number of neutrons $\times$ weight of a neutron + number of electrons $\times$ weight of an electron.

Molecular weight in $\mathrm{g} / \mathrm{Mol}$ was calculated from the weights of all atoms in a molecule multiplied by the Avogadro number $(6.023 \times$ $\left.10^{23}\right)$. The percent change in molecular weight was calculated using the following equation:

Percent change in molecular weight $=\left[\left(\mathrm{M}_{\mathrm{t}}-\mathrm{M}_{\mathrm{c}}\right) / \mathrm{M}_{\mathrm{c}}\right] \times 100$
Here, $M_{c}$ and $M_{t}$ are molecular weight of control and treated sample, respectively.

Percentage change in crystallite size was calculated using following formula:

Percentage change in crystallite size $=\left[\left(\mathrm{G}_{\mathrm{t}}-\mathrm{G}_{\mathrm{c}}\right) / \mathrm{G}_{\mathrm{c}}\right] \times 100$

Here, $G_{c}$ and $G_{t}$ are crystallite size of control and treated powder samples, respectively.

\section{Surface area analysis}

The surface area of both the control and treated samples was evaluated using the Brunauer-Emmett-Teller (BET) surface area analyzer, Smart SORB 90. Percent change in surface area was computed using following equation:

$\%$ change in surface area $=\frac{\left[\mathrm{S}_{\text {Treated }}-\mathrm{S}_{\text {Control }}\right]}{\mathrm{S}_{\text {Control }}} \times 100$

Here, $S_{\text {Control }}$ is the surface area of control sample and $S_{\text {Treated }}$ is the surface area of treated sample.

\section{DSC study}

The control and treated samples of $p$-anisidine were analyzed using a Pyris-6 Perkin Elmer differential scanning calorimeter. The heating rate was set to $10^{\circ} \mathrm{C} / \mathrm{min}$ under air atmosphere with air flow rate of $5 \mathrm{~mL} / \mathrm{min}$. An empty pan sealed with cover was used as the reference pan. The melting temperature $\left(\mathrm{T}_{\mathrm{m}}\right)$ and latent heat of fusion $(\Delta \mathrm{H})$ were obtained from the DSC thermogram.

\section{TGA-DTG analysis}

The TGA-DTG analysis was carried out in order to investigate the thermal stability of the control and treated $p$-anisidine. The studies were performed on Mettler Toledo simultaneous TGA-DTG system. Both the control and treated samples were heated from room temperature to $400^{\circ} \mathrm{C}$ with a heating rate of $5^{\circ} \mathrm{C} / \mathrm{min}$ under air atmosphere. The onset temperature (at which thermal degradation started) and $\mathrm{T}_{\max }$ (temperature at which maximum weight loss occur) in samples were obtained from DTG thermogram.

\section{Spectroscopic studies}

For the FT-IR and UV-Vis spectroscopic characterization, the treated sample was divided into two groups i.e., T1 and T2. These treated groups were then analyzed using FT-IR and UV-Vis spectroscopy and data were compared with respective data of control sample.

\section{FT-IR spectroscopic characterization}

The samples for FT-IR spectroscopy were prepared by crushing with spectroscopic grade $\mathrm{KBr}$ into fine powder. Finally, the mixture was pressed into pellets with a hydraulic press and then used for FT-IR analysis. The spectrum was recorded on Shimadzu's Fourier transform infrared spectrometer (Japan) with the frequency range of 500-4000 $\mathrm{cm}^{-1}$. The analysis was done to investigate the impact of biofield energy treatment at the atomic level like dipole moment, force constant, and bond strength in chemical structure [26].

\section{UV-Vis spectroscopic analysis}

The samples were prepared in methanol for UV spectroscopy. The UV spectra of the control and treated samples of $p$-anisidine were acquired on Shimadzu UV-2400 PC series spectrophotometer with quartz cuvette having slit widths of $2.0 \mathrm{~nm}$. The wavelength of UV analysis was set in the range of 200-400 $\mathrm{nm}$. This study was performed 
to evaluate the impact of biofield energy treatment on the energy gap of highest occupied molecular orbital and lowest unoccupied molecular orbital (HOMO-LUMO) [27].

\section{Results and Discussion}

\section{XRD analysis}

The XRD diffractograms of control and treated $p$-anisidine are shown in Figure 1. The control sample exhibited the XRD peaks at $2 \theta$ equal to $12.98^{\circ}, 13.19^{\circ}, 18.68^{\circ}, 18.89^{\circ}, 22.20^{\circ}, 25.70^{\circ}, 26.10^{\circ}, 26.63^{\circ}, 28.01^{\circ}$, and $28.49^{\circ}$. Similarly, the XRD diffractogram of treated $p$-anisidine showed the XRD peaks at $2 \theta$ equal to $13.16^{\circ}, 13.26^{\circ}, 18.75^{\circ}, 18.90^{\circ}$, $19.65^{\circ}, 22.09^{\circ}, 22.40^{\circ}, 24.24^{\circ}, 24.54^{\circ}$, and $28.31^{\circ}$. XRD diffractogram of both the control and treated $p$-anisidine showed the intense peaks that suggest the crystalline nature of $p$-anisidine. Figure 1 clearly showed the significant alteration in the intensity of XRD peaks in treated sample as compared to the control. In addition, control showed the most intense peak at 18.68 , whereas it was found at 24.24 in treated sample. It was reported that the change in crystal morphology causes the alteration in relative intensities of the peaks [28]. Furthermore, the alteration in $2 \theta$ values of treated sample as compared to the control indicated that an internal strain was probably present in the treated sample [29]. It is assumed that the energy, which probably transferred through biofield treatment, might induce the internal strain in the treated sample.

The unit cell volume, molecular weight and crystallite size of control and treated $p$-anisidine were computed using Powder X software and data are depicted in Table 1 . The unit cell volume of control and treated samples were found as 683.81 and $690.18 \times 10^{-24} \mathrm{~cm}^{3}$, respectively. The result showed slight increase in the unit cell volume in biofield treated sample as compared to control. Similarly, the molecular weight of treated sample was also increased slightly $(0.93 \%)$ with respect to the control. It is hypothesized that the biofield energy possibly acted on treated $p$-anisidine crystals at nuclear level and altered the number of proton and neutrons as compared to the control, which may led to increase the molecular weight.

The crystallite size of the control $p$-anisidine was observed as $83.84 \mathrm{~nm}$ that was increased to $84.62 \mathrm{~nm}$ in the treated sample. The result suggests a small increase in crystallite size of treated sample as compared to the control. It was reported that increase in annealing temperature significantly affects the crystallite size of the materials. The increase in temperature leads to decrease in dislocation density and increase in number of unit cell, which ultimately causes an increase in crystallite size [30,31]. It is postulated that biofield treatment may provide some thermal energy to $p$-anisidine molecules. As a result, the dislocation density might be reduced and thus the number of unit cell and crystallite size was increased.

\section{Surface area analysis}

The surface area of control and treated samples of $p$-anisidine was determined using BET surface area analyzer and data are presented in Figure 2. The surface area of the control and treated sample was found as $0.4638 \mathrm{~m}^{2} / \mathrm{g}$ and $0.5818 \mathrm{~m}^{2} / \mathrm{g}$, respectively. It showed a significant increase in surface area by $25.44 \%$ in the treated sample as compared to the control. It is well-reported that surface area is inversely proportional to the particle size [32]. Based on this, it was assumed that biofield energy treatment may provid the energy to the $p$-anisidine molecule that lead to reduction in particle size through energy milling [33]. In addition, the XRD data also indiacted that surface morpholgy of treated sample might changed after the biofield treatment, thus it could be a probable cause for increase in surface area. As a result the increase in surface area was observed in treated sample as compared to the control.

\section{DSC analysis}

DSC was used to determine the melting temperature and latent heat of fusion $(\Delta \mathrm{H})$ of the control and treated $p$-anisidine. DSC thermogram (Figure 3 ) of $p$-anisidine showed the melting temperature at $59.41^{\circ} \mathrm{C}$ in the control and $59.49^{\circ} \mathrm{C}$ in the treated sample (Table 2 ). The result suggests no change in melting temperature of treated sample as compared to the control. The melting temperature of control $p$-anisidine was well supported by literature data [34]. DSC thermogram exhibited the $\Delta \mathrm{H}$ of $146.78 \mathrm{~J} / \mathrm{g}$ in control sample and $148.89 \mathrm{~J} / \mathrm{g}$ in the treated sample of $p$-anisidine. The result showed about $1.44 \%$ increase in latent heat of fusion after biofield energy treatment with respect to the control. The existence of internal strain was evidenced by XRD data. Thus, it is assumed that presence of strain might cause to move the molecules toward each other. As a result, the intermolecular interaction in the treated sample might increase after the biofield treatment and that might be responsible for increase in the latent heat of fusion. Recently, our group has reported the biofield energy induced alteration in the value of latent heat of fusion of some metals like lead and tin [17].
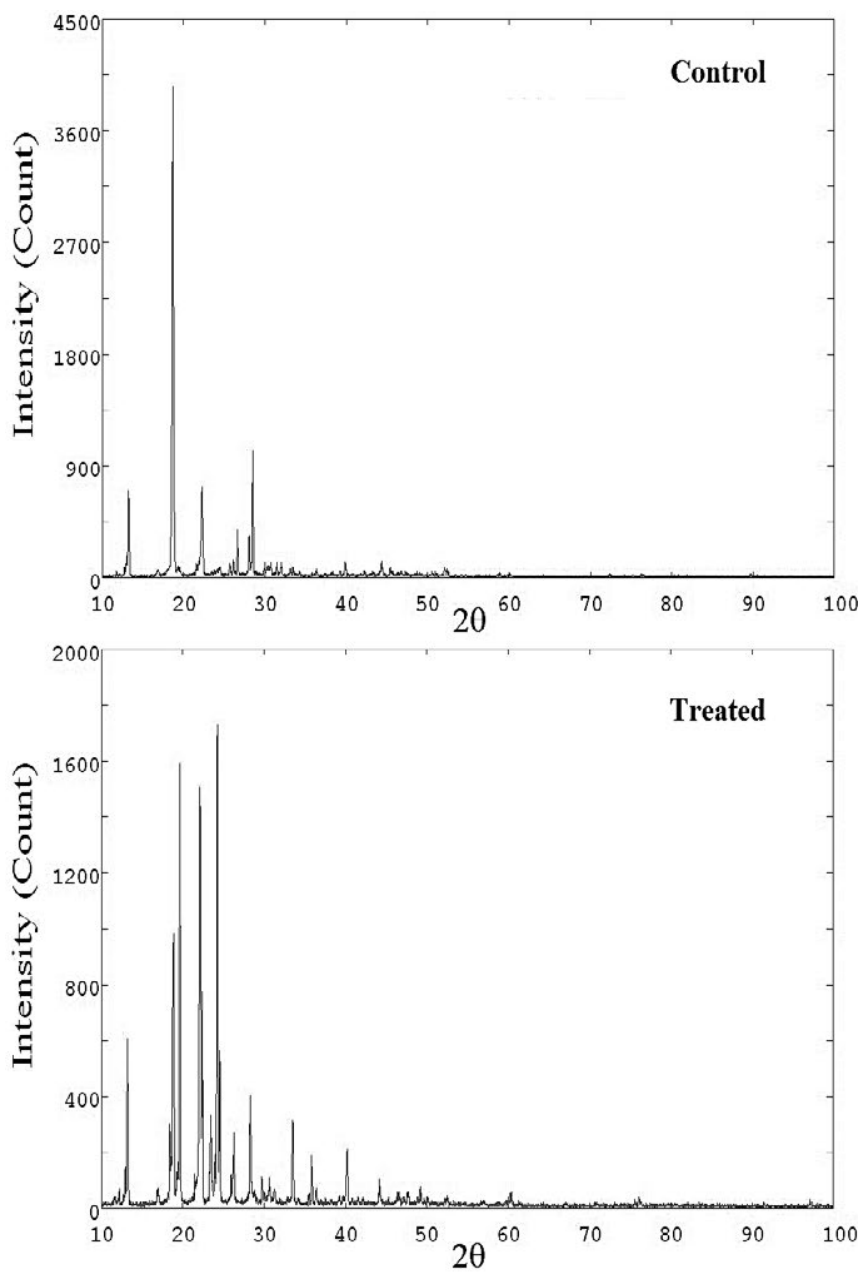

Figure 1: XRD diffractogram of $p$-anisidine. 
Citation: Trivedi MK, Branton A, Trivedi D, Nayak G, Bairwa K, et al (2015) Physicochemical and Spectroscopic Characterization of Biofield Energy Treated p-Anisidine. Pharm Anal Chem Open Access 1: 102. doi:10.4172/2471-2698.1000102

Page 4 of 8

\section{TGA-DTG analysis}

Thermogravimetric analysis is used to evaluate the vaporization, sublimation, and thermal degradation pattern of the samples. The TGA and DTG thermogram of control and treated samples of $p$-anisidine are shown in Figure 4 and the data are presented in Table 2. The onset temperature of thermal degradation was observed at $134.68^{\circ} \mathrm{C}$ and $150.02^{\circ} \mathrm{C}$ for the control and treated samples, respectively. While, the end-set temperature of thermal degradation was observed at $198.54^{\circ} \mathrm{C}$ and $206.21^{\circ} \mathrm{C}$ in the control and treated sample, respectively. This showed about $11.39 \%$ and $3.86 \%$ increase in the onset and end-set temperature, respectively after biofield treatment as compared to the control. Moreover, the percent weight loss during thermal decomposition was $70.07 \%$ in the control and $66.19 \%$ in the treated sample. The result showed decrease in percent weight loss during thermal decomposition after the biofield treatment. Based on this, it is presumed that biofield treated $p$-anisidine may be more thermally stable as compared to the control. The DTG thermogram exhibited the $\mathrm{T}_{\max }$ (the temperature at which the sample lost its maximum weight) at $165.99^{\circ} \mathrm{C}$ in the control sample and at $168.10^{\circ} \mathrm{C}$ in the treated sample of $p$-anisidine. The result revealed about $1.27 \%$ increase in $\mathrm{T}_{\max }$ of treated sample

\begin{tabular}{|l|c|c|}
\hline Parameter & Control & Treated \\
\hline Unit cell volume $\left(10^{-23} \mathrm{~cm}^{3}\right)$ & 683.81 & 690.18 \\
\hline Crystallite size $(\mathrm{nm})$ & 83.84 & 84.62 \\
\hline Molecular weight $(\mathrm{g} / \mathrm{mol})$ & 124.79 & 125.95 \\
\hline
\end{tabular}

Table 1: XRD data (volume of unit cell, crystallite size and molecular weight) of p-anisidine.

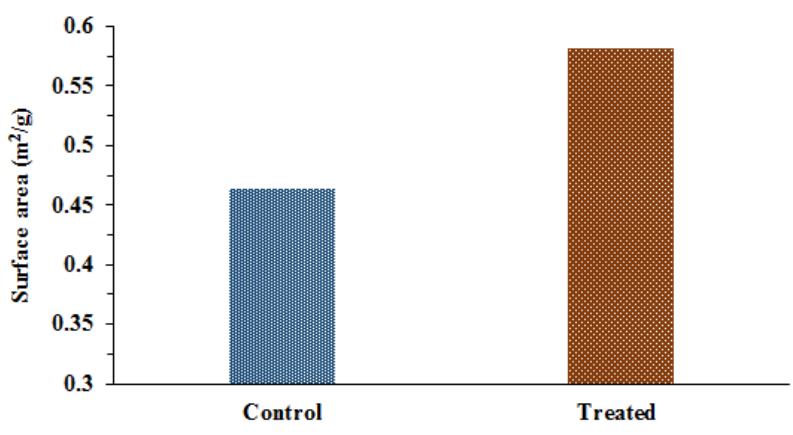

Figure 2: Surface area analysis of control and treated $p$-anisidine.
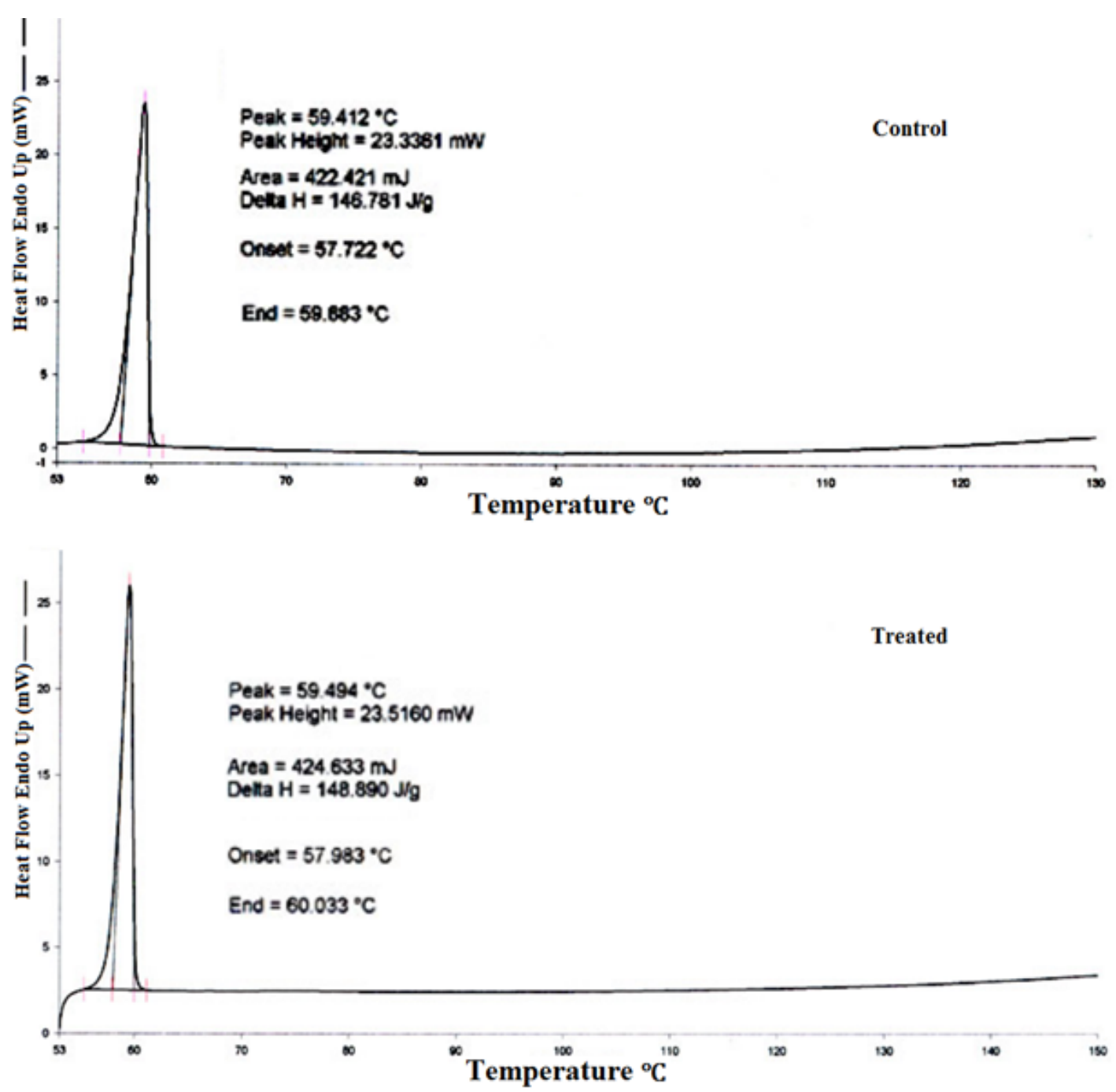

Figure 3: DSC thermogram of control and treated $p$-anisidine. 
Citation: Trivedi MK, Branton A, Trivedi D, Nayak G, Bairwa K, et al (2015) Physicochemical and Spectroscopic Characterization of Biofield Energy Treated p-Anisidine. Pharm Anal Chem Open Access 1: 102. doi:10.4172/2471-2698.1000102

Page 5 of 8

\begin{tabular}{|c|c|c} 
Parameter & Control & Treated \\
\hline Latent heat of fusion $(\mathrm{J} / \mathrm{g})$ & 146.78 & 148.89 \\
\hline Melting point $\left({ }^{\circ} \mathrm{C}\right)$ & 59.41 & 59.49 \\
\hline Onset temperature $\left({ }^{\circ} \mathrm{C}\right)$ & 134.68 & 150.02 \\
\hline End-set temperature $\left({ }^{\circ} \mathrm{C}\right)$ & 198.54 & 206.21 \\
\hline $\mathrm{T}_{\max }\left({ }^{\circ} \mathrm{C}\right)$ & 165.99 & 168.10
\end{tabular}

Table 2: Thermal analysis of control and treated samples of $p$-anisidine. $T_{\max }$ : Temperature at maximum weight loss occurs
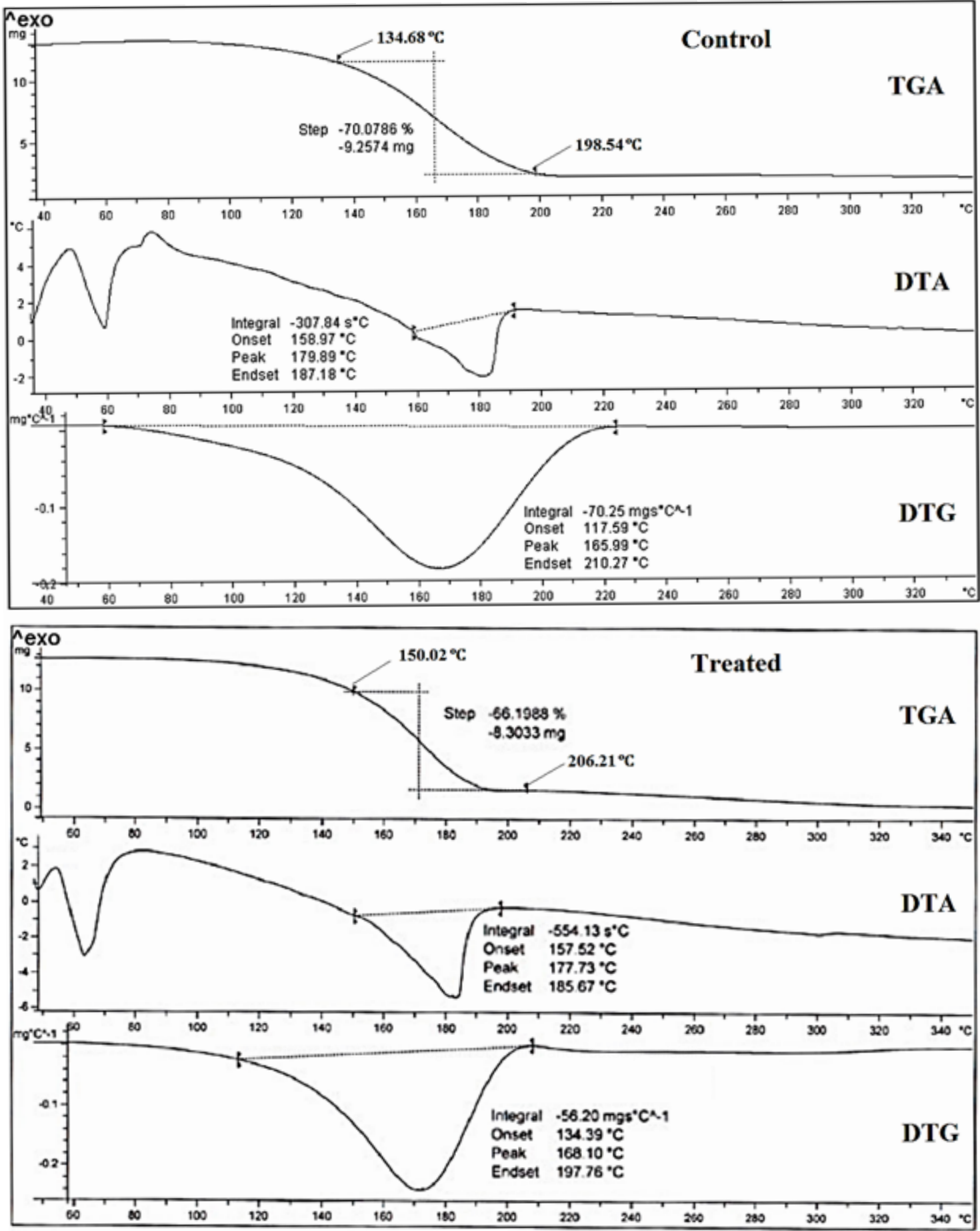

Figure 4: TGA-DTG thermogram of control and treated $p$-anisidine. 

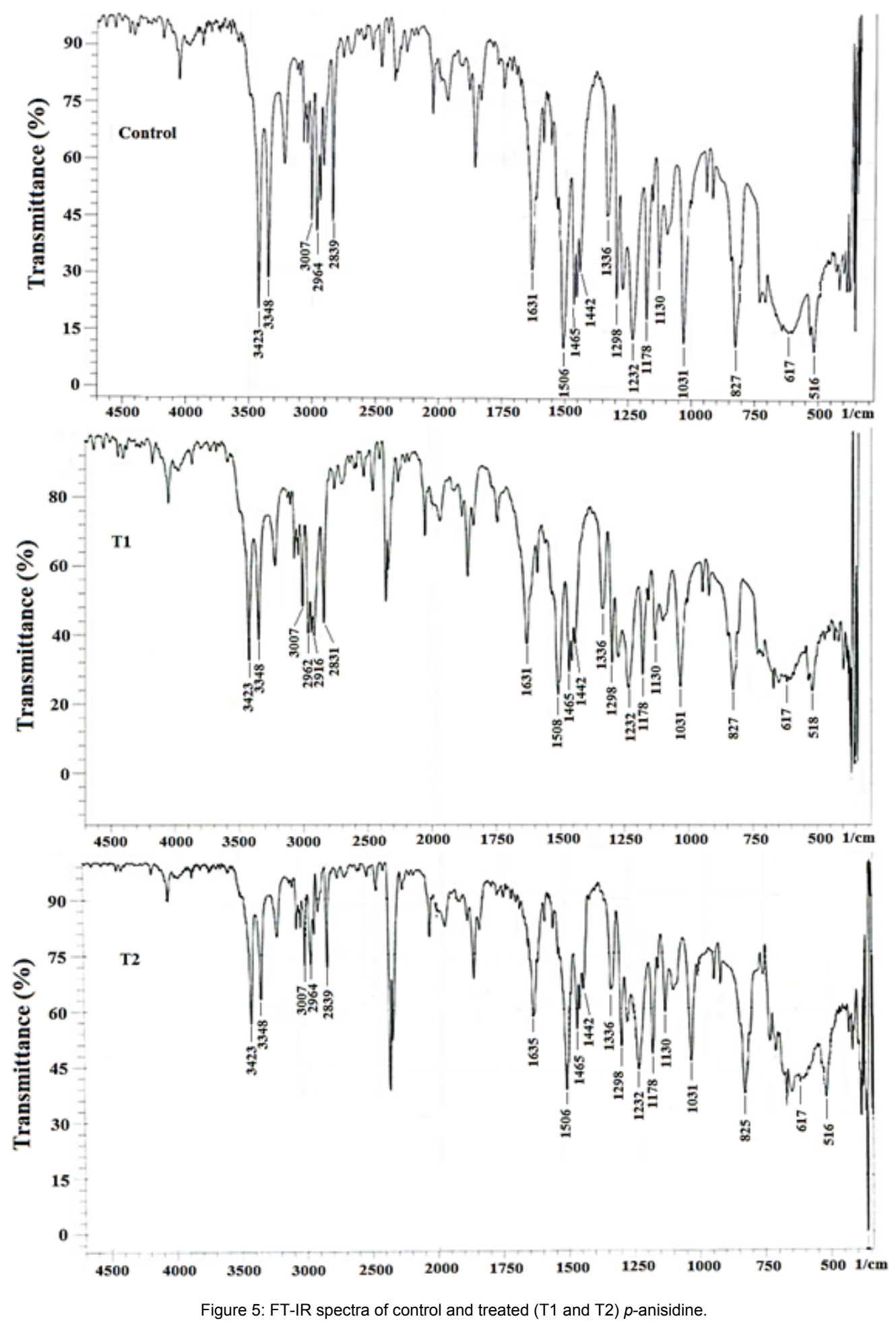

with respect to the control. This increase in $\mathrm{T}_{\max }$ in treated sample might be due to the alteration in internal energy through biofield energy treatment that results into enhanced thermal stability of treated sample as compared to the control. Overall, the result of this study showed the increase in onset temperature of thermal degradation and $\mathrm{T}_{\max }$. This might leads to decrease in the tendency of vaporization of $\mathrm{p}$-anisidine molecule. As a result, the environmental contamination due to vapors of $p$-anisidine (which is the major cause of $p$-anisidine toxicity) should be decreased drastically.

\section{FT-IR spectroscopic analysis}

FT-IR spectra of the control and treated samples of $p$-anisidine (Figure 5) were inferred with the help of theoretically predicted wavenumber. The $p$-anisidine molecule contains $\mathrm{N}-\mathrm{H},=\mathrm{C}-\mathrm{H}, \mathrm{C}=\mathrm{C}$, 

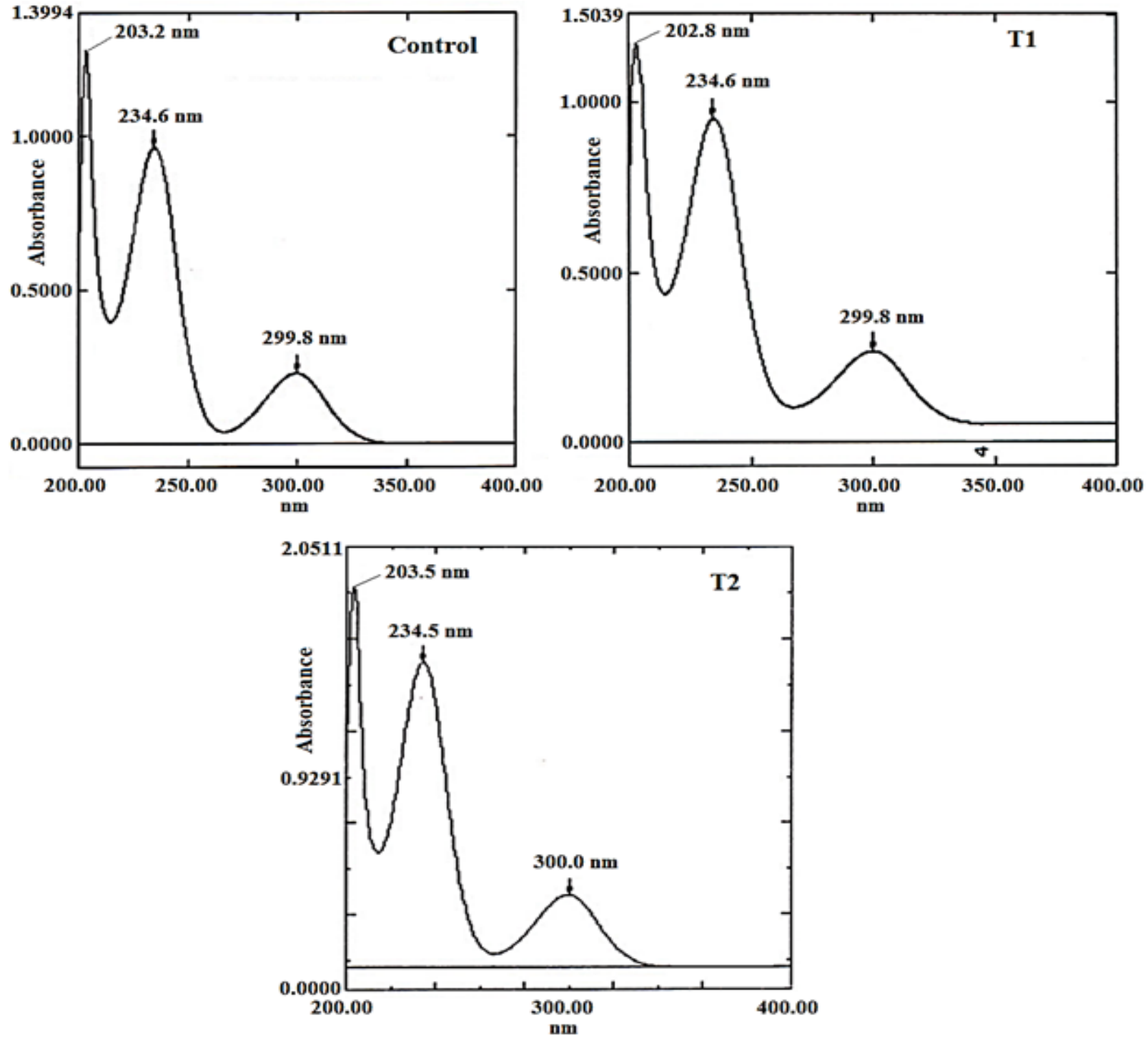

Figure 6: UV-Vis spectra of control and treated (T1 and T2) p-anisidine.

$\mathrm{C}-\mathrm{N}$, and $\mathrm{C}-\mathrm{O}$ bond vibrations. The $\mathrm{N}-\mathrm{H}$ stretching was assigned to peaks at $3348-3423 \mathrm{~cm}^{-1}$ in all the three samples i.e., the control and treated $(\mathrm{T} 1$ and $\mathrm{T} 2)$. Likewise, the $=\mathrm{C}-\mathrm{H}$ (aromatic) stretching was assigned to peak at $3007 \mathrm{~cm}^{-1}$ in all the three samples i.e., the control and treated ( $\mathrm{T} 1$ and $\mathrm{T} 2$ ). The $\mathrm{C}-\mathrm{H}$ stretching (methyl) was attributed to peaks appeared at 2839-2964 $\mathrm{cm}^{-1}$ in control, $2831-2962 \mathrm{~cm}^{-1}$ in T1 and $2839-2964 \mathrm{~cm}^{-1}$ in T2 sample. The aromatic $\mathrm{C}=\mathrm{C}$ stretching of aromatic ring was appeared in the region of $1506-1631 \mathrm{~cm}^{-1}$ in control, 1508-1631 $\mathrm{cm}^{-1}$ in $\mathrm{T} 1$ and $1506-1635 \mathrm{~cm}^{-1}$ in T2 sample. The C-H asymmetrical and symmetrical bending peaks were observed in the region of 1442$1465 \mathrm{~cm}^{-1}$ in all the samples i.e., control, T1 and T2. In addition, the $\mathrm{C}-\mathrm{N}$ stretching peak was observed at $1336 \mathrm{~cm}^{-1}$ in all the three samples. The C-O stretching for ether linkage was observed at 1031, $1298 \mathrm{~cm}^{-1}$ in all the three samples. The $=\mathrm{C}-\mathrm{H}$ in-plane deformation peaks were appeared at $1130-1178 \mathrm{~cm}^{-1}$ in all the three samples. Whereas, the C-H out of plane deformation peaks were appeared at $516-827 \mathrm{~cm}^{-1}$ control, $518-827 \mathrm{~cm}^{-1}$ in T1, and $516-825 \mathrm{~cm}^{-1}$ in T2 sample. The observed FTIR spectra were well supported with the literature data [35].

\section{UV-Vis spectroscopy}

The UV spectra of both control and treated (T1 and T2) samples are presented in Figure 6 . The UV spectrum of control $p$-anisidine showed the three different absorption maxima $\left(\lambda_{\text {max }}\right)$ at 203.2, 234.6, and 299.8 $\mathrm{nm}$. The UV spectrum of T1 sample showed the similar pattern of $\lambda_{\text {max }}$ i.e., at $202.8,234.6$, and $299.8 \mathrm{~nm}$. Whereas, the T2 sample exhibited the $\lambda_{\max }$ at $203.5,234.5$, and $300.0 \mathrm{~nm}$. The result suggested the similar pattern of $\lambda_{\max }$ in the treated samples as compared to the control. Overall, the UV-vis spectral analysis suggests that biofield energy treatment may not cause any significant change in the $\lambda_{\max }$ of treated $p$-anisidine samples with respect to the control.

\section{Conclusions}

In brief, the XRD diffractogram of biofield treated $p$-anisidine showed the slight increase in unit cell volume, crystallite size and molecular weight as compared to the control. The intensity of XRD peaks was also increased in treated sample as compared to the control. The surface area analysis showed a significant increase $(25.44 \%)$ in the 
Citation: Trivedi MK, Branton A, Trivedi D, Nayak G, Bairwa K, et al (2015) Physicochemical and Spectroscopic Characterization of Biofield Energy Treated p-Anisidine. Pharm Anal Chem Open Access 1: 102. doi:10.4172/2471-2698.1000102

surface area of biofield treated $p$-anisidine with respect to the control. The DSC analysis showed the slight increase in latent heat of fusion from $146.78 \mathrm{~J} / \mathrm{g}$ (control) to $148.89 \mathrm{~J} / \mathrm{g}$ in the treated sample. The TGA/ DTG analysis showed the increase in onset and end set temperature of thermal degradation by $11.39 \%$ and $3.86 \%$, respectively in treated sample with respect to the control. Moreover, the $\mathrm{T}_{\max }$ was also increased slightly from 165.99 (control) to $168.10^{\circ} \mathrm{C}$ in treated sample of $p$-anisidine.

Overall, it can be concluded that Mr. Trivedi's biofield energy treatment has the impact on physical and thermal properties of $p$-anisidine with respect to the control. Based on this, it is assumed that biofield treated $p$-anisidine could be more useful as a chemical intermediate in the organic synthesis of various dyes and pharmaceuticals.

\section{Acknowledgements}

The authors like to acknowledge the Trivedi Science, Trivedi Master Wellness and Trivedi Testimonials for their steady support during the work. Authors would also like to thanks the whole team from the MGV pharmacy college, Nasik for providing the instrumental facility.

\section{References}

1. Del Valle MA, Gacitua MA, Borrego ED, Zamora PP, Diaz FR, et al. (2012) Electro-synthesis and characterization of aniline and o-anisidine oligomers. Int J Electrochem Sci 7: 2552-2565.

2. Elsersawi A (2009) Chemistry, biology and cancer: The bond. Xlibris Corporation, USA.

3. Harbison RD, Bourgeois MM, Johnson GT (2015) Hamilton and Hardy's industrial toxicology. 6th edn. John Wiley \& Sons, New Jersey, USA.

4. WHO (1982) IARC Monographs on the evaluation of the carcinogenic risk of chemicals to humans. Some aromatic amines, anthraquinones and nitroso compounds, and inorganic fluorides use in drinking-water and dental preparations. Cancer 27.

5. Singh BP, Nyska A, Kissling GE, Lieuallen W, Johansson SL, et al. (2010) Urethral carcinoma and hyperplasia in male and female $\mathrm{B}_{6} \mathrm{C}_{3} \mathrm{~F}_{1}$ mice treated with 3,3',4,4'-tetrachloroazobenzene (TCAB). Toxicol Pathol 38: 372-381.

6. Hok J, Tishelman C, Ploner A, Forss A, Falkenberg T (2008) Mapping patterns of complementary and alternative medicine use in cancer: An explorative crosssectional study of individuals with reported positive "exceptional" experiences. BMC Complement Altern Med 8: 48.

7. Koithan M (2009) Introducing complementary and alternative therapies. Nurse Pract 5: 18-20.

8. Aldridge D (1991) Spirituality, healing and medicine. Br J Gen Pract 41: 425427.

9. Cahil M (1998) Nurses handbook of complementary and alternative therapies Springhouse, PA: Springhouse Corporation.

10. Movaffaghi Z, Farsi M (2009) Biofield therapies: Biophysical basis and biological regulations? Complement Ther Clin Pract 15: 35-37.

11. Maxwell JC (1865) A dynamical theory of the electromagnetic field. Phil Trans R Soc Lond 155: 459-512.

12. Rubik B (2002) The biofield hypothesis: Its biophysical basis and role in medicine. J Altern Complement Med 8: 703-717.

13. Rubik B, Brooks AJ, Schwartz GE (2006) In vitro effect of Reiki treatment on bacterial cultures: Role of experimental context and practitioner wellbeing. J Altern Complement Med 12: 7-13.

14. Benor DJ (1990) Survey of spiritual healing research. Complement Med Res 4: 9-33.

15. Rein $\mathrm{G}$ (1995) The in vitro effect of bioenergy on conformational state of human DNA in aqueous solutions. Acupunct Electrother Res 20: 173-180.

16. Trivedi MK, Tallapragada RM, Branton A, Trivedi D, Nayak G, et al. (2015) Potential impact of biofield treatment on atomic and physical characteristics of magnesium. Vitam Miner 3: 129.
17. Trivedi MK, Patil S, Tallapragada RM (2013) Effect of biofield treatment on the physical and thermal characteristics of silicon, tin and lead powders. J Material Sci Eng 2: 125.

18. Trivedi MK, Nayak G, Patil S, Tallapragada RM, Latiyal O (2015) Evaluation of biofield treatment on physical, atomic and structural characteristics of manganese (II, III) oxide. J Material Sci Eng 4: 177

19. Trivedi MK, Patil S, Shettigar H, Bairwa K, Jana S (2015) Spectroscopic characterization of chloramphenicol and tetracycline: An impact of biofield. Pharm Anal Acta 6: 395

20. Trivedi MK, Patil S, Shettigar H, Bairwa K, Jana S (2015) Spectroscopic characterization of biofield treated metronidazole and tinidazole. Med Chem 5: 340-344.

21. Nayak G, Altekar N (2015) Effect of biofield treatment on plant growth and adaptation. J Environ Health Sci 1: 1-9.

22. Lenssen AW (2013) Biofield and fungicide seed treatment influences on soybean productivity, seed quality and weed community. Agricultural Journal 8: $138-143$.

23. Shinde V, Sances F, Patil S, Spence A (2012) Impact of biofield treatment on growth and yield of lettuce and tomato. Aust J Basic Appl Sci 6: 100-105.

24. Trivedi MK, Patil S, Shettigar H, Mondal SC, Jana S (2015) Evaluation of biofield modality on viral load of Hepatitis B and $C$ viruses. J Antivir Antiretrovir 7: 83-88.

25. Trivedi MK, Patil S, Shettigar H, Gangwar M, Jana S (2015) Antimicrobial sensitivity pattern of $P$ seudomonas fluorescens after biofield treatment. J Infect Dis Ther 3: 222.

26. Patterson AL (1939) The Scherrer formula for X-Ray particle size determination Phys Rev 56: 978-982.

27. Pavia DL, Lampman GM, Kriz GS (2001) Introduction to spectroscopy. (3rdedn), Thomson Learning, Singapore.

28. Inoue M, Hirasawa I (2013) The relationship between crystal morphology and XRD peak intensity on $\mathrm{CaSO}_{4} \cdot 2 \mathrm{H}_{2} \mathrm{O}$. J Cryst Growth 380: 169-175.

29. Fultz B, Howe JM (2002) In Transmission electron microscopy and diffractometry of materials. Diffraction and the X-ray powder diffractometer. 4th edn. Springer-Verlag: Berlin.

30. Gaber A, Abdel-Rahim MA, Abdel-Latief AY, Abdel-Salam MN (2014) Influence of calcination temperature on the structure and porosity of nanocrystalline $\mathrm{SnO}_{2}$ synthesized by a conventional precipitation method. Int $\mathrm{J}$ Electrochem Sci 9 ? 81-95.

31. Raj KJA, Viswanathan B (2009) Effect of surface area, pore volume, particle size of P25 titania on the phase transformation of anatase to rutile. Indian J Chem 48A: 1378-1382.

32. Groza JR, Shackelford JF (2007) Materials processing handbook. Taylor and Francis group, CRC Press.

33. Trivedi MK, Nayak G, Patil S, Tallapragada RM, Latiyal O (2015) Studies of the atomic and crystalline characteristics of ceramic oxide nano powders after bio field treatment. Ind Eng Manage 4: 161

34. http://www.merckmillipore.com/IN/en/product/p-Anisidine,MDA_CHEM 845003

35. http://www.chem.ucla.edu/ bacher/General/30BL/problems/spectroscopy/ assignmentW14/key.html.

Citation: Trivedi MK, Branton A, Trivedi D, Nayak G, Bairwa K, et al (2015) Physicochemical and Spectroscopic Characterization of Biofield Energy Treated $p$-Anisidine. Pharm Anal Chem Open Access 1: 102. doi:10.4172/2471 2698.1000102 